\title{
October 2013 Tucson Pulmonary Journal Club: Tiotropium Respimat
}

\author{
Wise RA, Anzueto A, Cotton D, Dahl R, Devins T, Disse B, Dusser D, Joseph E, \\ Kattenbeck S, Koenen-Bergmann M, Pledger G, Calverley P; TIOSPIR \\ Investigators. Tiotropium Respimat inhaler and the risk of death in COPD. N Engl \\ J Med. 2013;369(16):1491-501. [CrossRef] [PubMed]
}

Tiotropium, a long-acting inhaled anticholingeric bronchodilator, is commonly used to prevent COPD exacerbations (1). Tiotropium is available as a dry powder (HandiHaler) or aqueous solution (Respimat). Direct comparisons of the two formulations are lacking. Prior post-hoc analyses suggest that that Respimat may be more efficacious than HandiHaler (2) but it may also increase the risk of death, particularly among those with cardiac dysrhythmias (3-6).

The two were recently compared in a large randomized, double-blind, parallel trial of once daily treatment with Respimat $(2.5 \mu \mathrm{g}$ or $5 \mu \mathrm{g})$ or HandiHaler $(18 \mu \mathrm{g})$. [add REF here] Inclusion criteria included a COPD diagnosis, a 10 pack year smoking history, and post-bronchodilator $\mathrm{FEV}_{1} / \mathrm{FVC}$ ratio $\leq 0.70$ and $\mathrm{FEV}_{1} \leq 70 \%$ of predicted. Major exclusion criteria included a myocardial infarction within past 6 months, hospitalization for Class III or IV heart failure, or unstable or life-threatening arrhythmia requiring new treatment within the previous 12 months. The primary safety outcome was all cause mortality and the primary efficacy outcome was first COPD exacerbation. Importantly, mortality was tested using a non-inferiority approach with a pre-specified non-inferiority margin of 1.25 .

Approximately 17,000 participants (71\% male) were followed for a median of 2.3 years. Their mean age was 65 years, average $\mathrm{FEV}_{1}$ was $48 \%$ of predicted, previous ischemic heart disease was present in $15 \%$, and previous cardiac dysrhythmia was present in $10 \%$. During the study, $1302(7.6 \%)$ deaths were recorded. The hazard ratio for allcause mortality comparing Respimat $5 \mu \mathrm{g}$ versus HandiHaler $18 \mu \mathrm{g}$ (referent) was 0.96 $\left(\mathrm{Cl}_{95 \%}\right.$ 0.84-1.09) indicating that Respimat was non-inferior to HandiHaler. The hazard ratio for first exacerbation was $0.98\left(\mathrm{Cl}_{95 \%}\right.$ 0.93-1.03) indicating that Respimat was not superior to HandiHaler. While mortality among participants with prior cardiac dysrhythmias was not higher in the Respimat group, HR 0.81 ( $\mathrm{Cl}_{95 \%}$ 0.58-1.12), myocardial infarctions among the Respimat group were marginally more frequent $\mathrm{HR}$ $1.41\left(\mathrm{Cl}_{95 \%}\right.$ 0.98-2.00; $\left.\mathrm{p}=0.06\right)$.

Notable strengths of the study included its large, prospective, head-to-head design with double-blinding of treatment assignment. Follow-up was lengthy and well described; loss-to-follow-up was negligible. The non-inferiority analysis of all-cause mortality provides convincing evidence that no meaningful difference in the risk of death is likely between the two Tiotropium formulations.

Without a placebo control, this study does not provide information with regard to the potential class effect of Tiotropium on all-cause or cardiac specific mortality. The weak $(p=0.06)$ signal suggesting a link between Respimat and increased risk of myocardial 
infarction was unexpected and remains unexplained. During our discussion, we could not identify a mechanistic pathway that might account for a differential effect of the aqueous and dry powder Tiotropium formulations. Without a credible link, the probability of a false positive signal is high. Nevertheless, future analyses of secondary and/or claims data looking for evidence to support a link between Respimat and ischemic events may be warranted.

Abdulmagid Eddib MD Joe Gerald MD PhD

Cristine Berry MD

University of Arizona

Tucson, Arizona

\section{References}

1. Vogelmeier $\mathrm{C}$, Hederer $\mathrm{B}$, Glaab $\mathrm{T}$, et al. Tiotropium versus salmeterol for the prevention of exacerbations of COPD. N Engl J Med 2011;364:1093-103. [CrossRef] [PubMed]

2. Asakura Y, Nishimura N, Maezawa K, Terajima T, Kizu J, Chohnabayashi N. Effect of switching tiotropium HandiHaler ${ }^{\circledR}$ to Respimat ${ }^{\circledR}$ Soft Mist ${ }^{\mathrm{TM}}$ Inhaler in patients with COPD: the difference of adverse events and usability between inhaler devices. J Aerosol Med Pulm Drug Deliv. 2013 Feb;26(1):41-5. [CrossRef] [PubMed]

3. Singh S, Loke YK, Enright PL, Furberg CD. Mortality associated with tiotropium mist inhaler in patients with chronic obstructive pulmonary disease: systematic review and meta-analysis of randomized controlled trials. BMJ 2011;342:d3215. [CrossRef] [PubMed]

4. Karner C, Chong J, Poole P. Tiotropium versus placebo for chronic obstructive pulmonary disease. Cochrane Database Syst Rev. 2012;7:CD009285. [CrossRef] [PubMed]

5. Dong $\mathrm{YH}$, Lin $\mathrm{HH}$, Shau WY, Wu YC, Chang $\mathrm{CH}$, Lai MS. Comparative safety of inhaled medications in patients with chronic obstructive pulmonary disease: systematic review and mixed treatment comparison meta-analysis of randomized controlled trials. Thorax 2013;68:48-56. [CrossRef] [PubMed]

6. Loke YK, Singh S. Risks associated with tiotropium in chronic obstructive pulmonary disease: overview of the evidence to date. Ther Adv Drug Safe 2012;3:123-31. [CrossRef] 